\title{
Barriers to the adoption of green operational practices at Brazilian companies: effects on green and operational performance
}

\author{
Charbel José Chiappetta Jabbour, Ana Beatriz Lopes de Sousa Jabbour, \\ Kannan Govindan, Thiago Pignatti de Freitas, Davi Fouad Soubihia, Devika \\ Kannan \& Hengky Latan
}

To cite this article: Charbel José Chiappetta Jabbour, Ana Beatriz Lopes de Sousa Jabbour, Kannan Govindan, Thiago Pignatti de Freitas, Davi Fouad Soubihia, Devika Kannan \& Hengky Latan (2016) Barriers to the adoption of green operational practices at Brazilian companies: effects on green and operational performance, International Journal of Production Research, 54:10, 3042-3058, DOI: $10.1080 / 00207543.2016 .1154997$

To link to this article: https://doi.org/10.1080/00207543.2016.1154997

\section{曲 Published online: 25 Mar 2016.}

Submit your article to this journal \lceil

Џ Article views: 574

View Crossmark data ¿

Citing articles: 18 View citing articles $\square$ 


\title{
Barriers to the adoption of green operational practices at Brazilian companies: effects on green and operational performance
}

\author{
Charbel José Chiappetta Jabbour ${ }^{\mathrm{a} *}$, Ana Beatriz Lopes de Sousa Jabbour ${ }^{\mathrm{a}}$, Kannan Govindan ${ }^{\mathrm{b}}$, \\ Thiago Pignatti de Freitas ${ }^{\mathrm{a}}$, Davi Fouad Soubihia ${ }^{\mathrm{a}}$, Devika Kannan ${ }^{\mathrm{b}}$ and Hengky Latan ${ }^{\mathrm{c}}$ \\ ${ }^{a}$ Department of Production Engineering, UNESP - Sao Paulo State University (Univ Estadual Paulista), Sao Paulo, Brazil; ${ }^{b}$ Department \\ of Technology and Innovation, Centre for Sustainable Engineering Operations Management, University of Southern Denmark, Odense \\ M, Denmark; ${ }^{c}$ Faculty of Economics and Business, Department of Accounting, Universitas Pattimura, Ambon, Indonesia
}

(Received 16 March 2015; accepted 2 February 2016)

\begin{abstract}
The objective of this paper is to verify to what degree the internal and external barriers (I/EBs) to environmental management affect the adoption of green operational practices (GOPs) and to determine whether they influence the firms' operational and green performance in a sample of Brazilian companies. A conceptual framework with 8 hypotheses is proposed and tested at 75 companies using Partial Least Squares-Structural Equation Modeling (PLS-SEM) with WarpPLS 4.0. The main results show that (a) the proposed framework obtained an adequate statistical adjustment, (b) the internal barriers (IBs) are more significant than the EBs when adopting GOPs, (c) GOPs relate directly to the firms' green and operational performance (OP), (d) the IBs also indirectly influence the firms' green and OP and (e) the firm size does not significantly influence its green and OP. This work contributes to the literature by showing that companies which are looking for green competitive advantages should try to reduce their IBs. Also, policy-makers should pay attention not only to legislation that promotes ecological modernisation, but also to create a strong set of initiatives to overcome IBs, regardless of the size of the firms.
\end{abstract}

Keywords: green manufacturing; sustainable operations; sustainability; production and operations management; barriers; performance; Brazil

\section{Introduction}

This research's main motivation is to discover whether internal barriers (IBs) and external barriers (EBs) to environmental management affect the adoption of green operational practices (GOPs) and to determine whether they influence the firms' operational performance (OP) and green performance (GP) indicators within Brazilian industrial companies.

Generally, barriers related to green management are internal or external, and tend to inhibit the forward movement of greening in organisations (Hillary 2004), and those firms that support environmentally responsible manufacturing may face many challenges (Handifield et al. 2001). Several studies exist to identify these barriers to green practices (Hillary 2004; Studer, Welford, and Hills 2006; Kehbila, Ertel, and Brent 2009; Chan 2011).

Three types of green management practices exist: planning and organisational, operational and communication-based approaches (González-Benito and González-Benito 2006). Among these, GOPs have greater potential for changing green operations performance because they act on resource consumption and waste generation aspects. According to Schrettle et al. (2014), green operations management is the main driver of sustainable companies. However, the studies that deal with the discussion of green management practices and barriers focus on planning and organisational practices, with an emphasis on environmental management systems (Hillary 2004; Kehbila, Ertel, and Brent 2009; Cordano, Marshall, and Silverman 2010; Chan 2011). Thus, a direct link between environmental barriers and GOPs is still unclear. The effects of GOPs on company performance indicators also need to be better understood because, up to now, most studies tend to analyse the effects of green management from an economic perspective (Schaltegger and Synnestvedt 2002; Wagner 2005; de Burgos-Jiménez et al. 2013). Therefore, the literature has few studies on the effects of green barriers and GOPs on firms' operational and green indicators.

Based on the above considerations, and in correlation with Ervin et al. (2013), who have established that it is necessary to move forward in the understanding of green management barriers at companies, the objective of this paper is to verify to what degree the IBs and EBs to environmental management affect the adoption of GOPs and to determine

\footnotetext{
*Corresponding author. Email: charbel@feb.unesp.br 
whether they influence the firms' OP and GP. According to Walker, Di Sisto and McBain (2008), barriers to environmental management tend to vary according to the organisational context, and thus, in line with the above objectives, a survey was conducted with ISO 9001-certified manufacturing companies located in Brazil. According to Massoud et al. (2015), companies with ISO 9001 tend to be more motivated to adopt environmental management initiatives. Terziovski, Power and Sohal (2003) found that organisations that pursue ISO 9001 certification are more likely to report improved organisational performance. Thus, ISO 9001 can be relevant when pursuing environmental performance. The structural equation modelling technique (Peng and Lai 2012) was used to evaluate the research hypotheses.

The originality of this study is summarised as follows:

- This study gathers various important concepts into a single conceptual framework which, until now, has been considered separately in the literature. We employ theoretical implications based on ecological modernisation (Sarkis, Zhu, and Lai 2011; Lai, Wong, and Cheng 2012) and a natural resource-based view of the firms (Hart 1995; Sarkis, Zhu, and Lai 2011; Dangelico in press). Understanding IBs and EBs can be relevant to improve GP and OP, helping managers to achieve a better fit between the adoption of GOPs and performance.

- The study was conducted at manufacturing companies located in Brazil, an emerging economy, a member of the BRIC countries and the nation responsible for nearly $30 \%$ of the wealth generated in Latin America (Jabbour and Jabbour 2014). Discussing green operations management in Brazil is relevant because Brazil is likely to keep its position as one of the top-10 economies by 2050 (PWC 2015). Other recent works explored green barriers in China (Abdulrahman, Gunasekaran, and Subramanian 2014) and in India (Mittal and Sangwan 2014), but no similar research with empirical evidence from Brazil exists. On the other hand, Brazil has idiosyncrasies, such as its New Policy on Solid Waste (NPSW) (Jabbour et al. 2014) and its new agreements with the USA (Whitehouse 2015) to drop carbon emissions and increase the adoption of cleaner technologies, which could encourage firms to adopt greener practices. Additionally, Brazilian companies tend to face more competitive challenges when doing business because the country is posed in a much lower position than the USA or China in terms of Global Competitiveness Indicators (Sala-I-Martín et al. 2014). Finally, it is necessary to recognise that Brazilian managerial style may have some particularities in terms of cultural attitudes when adopting and adapting worldwide management practices. As discussed by Caldas and Wood (1997), Brazilian companies may face more challenges when adopting managerial practices than their managers would like to present to external observers. The aforementioned cultural characteristics of the companies transform Brazil in a unique place when studying adoption of managerial practices (Caldas and Wood 1997). In summary, the Brazilian context can be considered different from either American or Chinese contexts and requires a specific discussion about the hypotheses tested in this work.

This paper is organised into six sections. After the Introduction (Section 1), Research Framework and Hypotheses Development (Section 2) are presented. In Section 3, our research methodology is presented which details the procedures for collecting and analysing data. Results and an analysis based on the verification of the research hypotheses are presented in Section 4. Section 5 features the discussions and highlights the contributions of this study in the light of the previous literature. Finally, in Section 6, we present our conclusions, research implications and limitations.

\section{Research framework and hypotheses development}

Brazil is in a context of creating new environmental laws, as the New Policy for Solid Waste (created in 2010 and started implementing from 2014), strives to promote pollution prevention and reverse logistics for both public and private organisations (Jabbour et al. 2014). This national context could be understood through the lens of Ecological Modernisation theory (Sarkis, Zhu, and Lai 2011) and this new set of environmental laws can induce organisations to innovate and to include green improvements in their operations. Ecological modernisation can be used to understand developing countries in a greener context (Lai, Wong, and Cheng 2012). As a consequence of responding to this greener context, organisations must adopt internal green practices, which requires using their own resources and capabilities to achieve competitiveness based on environmental management (Wong et al. 2012) and to create better performance and value (Wong, Wong, and Boon-itt 2013). For example, by focusing on pollution prevention and product development, organisations may create competitive advantages and better performance based on green issues. Thus, a natural resources-based view (NRBV) of the firms (Hart 1995) indicates that companies need to mobilise their resources and to overcome barriers to gain green competitive advantages. This translation process, from the external ecological modernisation context to the internal green practices adoption and creation of competitive advantage, could be considered a challenge that deserves more research (Lai, Wong, and Cheng 2012).

The resource-based view of the firms considers that firms' internal resources and capabilities are competitive and exhibit certain sustained advantages (Grant 1991; Hart and Dowell 2011). Some examples of resources and capabilities 
include technologies, equipment, location, access to raw materials, training, organisational learning and stakeholders' management.

The aforementioned capabilities can improve a firm's organisational performance (Schroeder et al. 2002) and its environmental proactivity and strategy (Sharma and Vredenburg 1998). In general, contemporary research in proactive environmental management has reinforced that there is a need for developing resources and capabilities that will culminate in better competitive advantages and performance (Hart 1995; Leoniduo et al. in press; Martín-de Castro, Amores-Salvadó, and Navas-López in press).

As a consequence, any difficulty in managing resources and capabilities can increase the barriers to a proactive environmental management and will complicate the search for better organisational performance.

At the organisational level, the effects of environmental management and NRBW will require the adoption of compulsory environmental management practices (Sarkis, Zhu, and Lai 2011). As explained in Section 1, among the various types of environmental management practices and approaches, those that are operational (GOPs) in the context of a search for green operations management (Schrettle et al. 2014) deserve to be highlighted. GOPs relate the companies' production activities and are responsible for the main environmental impacts generated in manufacturing. As shown by Ubeda, Arcelus and Faulin (2011), based on the study of a large company in Spain, the adoption of green operations can be related to the firm's gains. The adoption of GOPs and other internal environmental management practices should be a long-term process to achieve economically positive performance (Gotschol, De Giovanni, and Esposito Vinzi 2014).

Table 1 says the main GOPs focused on production processes at manufacturing companies. The selected GOP variables are based on the highly referred works of González-Benito and González-Benito $(2005,2006)$ and other authors in the field (Gupta 1995; Handfield et al. 1997; Angell and Klassen 1999). Lin and Ho (2011) determined that the relative advantage and compatibility of green practices, organisational supports, human resources, regulatory pressures and governmental supports are associated with GOPs' adoption in the Chinese context. According to Gavronski et al. (2011), green process management requires the support of other resources, such as environmental investments and top management commitment.

On one side, GOPs' related issues can be considered as the most relevant approach when pursuing sustainability in organisations (Schrettle et al. 2014). However, on the other side, it is critical to understand better ways of facilitating the adoption of GOPs in firms from developing countries (Kuei et al. 2013). While many works adequately discuss the drivers (Large and Gimezes-Thomsen 2011), motivations (Gravonski et al. 2008) and green enablers (Kuei et al. 2013), opportunities still exist to understand barriers to GOPs' adoption in organisations of developing countries.

However, in this context, a series of barriers could be generating obstacles to the greening of firms (Hillary 2004; Studer, Welford, and Hills 2006; Collins et al. 2007; Kehbila, Ertel, and Brent 2009; Chan 2011). Mittal and Sangwan (2014) affirm that there are barriers which hinder the implementation of GOPs in developing countries. The prioritisation of the barriers from different perspectives is expected to help the decision-/policy-makers in government and industry to mitigate these barriers in a more effective manner.

One of the first works about barriers to green management considered two types of barriers (Post and Altma 1994): organisational barriers (employee attitude, inadequate top management leadership, poor communications, past practice and uncertainty about potential results) and industrial barriers (capital costs, competitive pressures, industry regulations and technical information). Organisational barriers are internal to the firm, whereas industrial barriers represent external challenges to the firm.

According to Post and Altma's (1994) perspective, and repeated by the most-cited studies in the area (Hillary 2004; Chan 2008; Shi et al. 2008; Murillo-Luna, Garcés-Ayerbe, and Rivera-Torres 2011), barriers to green management can be internal (IB) or external (EB). IBs correspond to obstacles that start within the company and avoid or impede the adoption or implementation of environmental management initiatives (Hillary 2004). These barriers are firm-specific factors which hinder environmental protection, but they can be controlled by assigning required resources (Murillo-Luna, Garcés-Ayerbe, and Rivera-Torres 2011). EBs emerge from outside the company and avoid or impede the adoption or implementation of green management initiatives (Hillary 2004). EBs also denote environmental factors or aspects which cannot be directly controlled by a firm (Murillo-Luna, Garcés-Ayerbe, and Rivera-Torres 2011).

In this line, based on the reality of Spain, Murillo-Luna, Garcés-Ayerbe and Rivera-Torres (2011) note that organisational managers face both EBs and IBs, but that IBs are more significant because they damage environmental management and they generate endemic problems. These endemic limitations include aspects such as (a) limited financial capabilities for environmental investment, (b) low employee involvement in decision-making, (c) lack of technological information and communication capabilities, (d) aversion to innovation and (e) deficient investment of resources in R\&D. 
Table 1. Research constructs and variables.

\begin{tabular}{|c|c|c|}
\hline Construct & Variables/items/indicators & Adapted from \\
\hline $\begin{array}{l}\text { External barriers } \\
\text { (EBs) }\end{array}$ & $\begin{array}{l}\text { V1 - Shortage of information on environmental legislation } \\
\text { V2 - Lack of clarity on environmental legislation } \\
\text { V3 - Difficulties associated with the environmental legislation } \\
\text { application and monitoring process } \\
\text { V4 - Lack of flexibility in compliance with legal deadlines } \\
\text { V5 - Lack of flexibility in compliance with legal demands } \\
\text { V6 - Shortage of services/technologies for environmental } \\
\text { improvement } \\
\text { V7 - Insufficient supply of consulting services/advice on } \\
\text { environmental management } \\
\text { V8 - Insufficient supply of equipment for environmental } \\
\text { improvement } \\
\text { V9 - Uncertainty about the effects of environmental } \\
\text { management in company results } \\
\text { V10 - Difficulty in conducting environmental management } \\
\text { and maintaining competitive prices at the same time } \\
\text { V11 - High cost of environmental services and technologies } \\
\text { applied to production processes } \\
\text { V12 - High cost of environmental services and technologies } \\
\text { applied to the development of new products } \\
\text { V13 - Perception of high complexity in implementing an } \\
\text { environmental management system } \\
\text { V14 - More concerns with other aspects than with } \\
\text { environmental management }\end{array}$ & $\begin{array}{l}\text { Murillo-Luna, Garcés-Ayerbe, and Rivera-Torres } \\
\text { (2011) }\end{array}$ \\
\hline $\begin{array}{l}\text { Internal barriers } \\
\quad(\text { IBs })\end{array}$ & $\begin{array}{l}\text { V15 - Limited financial capacity for environmental } \\
\text { investments } \\
\text { V16 - At my company, there is reduced participation of } \\
\text { workers in decision-making } \\
\text { V17 - Technological information and advances in } \\
\text { communication are not available } \\
\text { V18 - Aversion to innovative projects due to the risk involved } \\
\text { V19 - Little investment in research and development for } \\
\text { products } \\
\text { V20 - Lack of environmental training for employees } \\
\text { V21 - Lack of environmental training for directors/owners } \\
\text { V22 - Employees have limited environmental awareness } \\
\text { V23 - Directors/owners have limited environmental awareness } \\
\text { V24 - Workers avoid to change in work habits } \\
\text { V25 - Directors/owners resist change in work habits }\end{array}$ & $\begin{array}{l}\text { Murillo-Luna, Garcés-Ayerbe, and Rivera-Torres } \\
\text { (2011) }\end{array}$ \\
\hline $\begin{array}{l}\text { Green } \\
\text { operational } \\
\text { practices } \\
\text { (GOPs) }\end{array}$ & $\begin{array}{l}\text { V26 - Replacement of polluting or hazardous materials or } \\
\text { components } \\
\text { V27 - Product development focused on reducing consumption } \\
\text { of material and waste generation during production and } \\
\text { distribution } \\
\text { V28 - Product development focused on reducing consumption } \\
\text { of material and waste generation during consumption } \\
\text { V29 - Emission filters and pollution controls at the end of the } \\
\text { production process } \\
\text { V30 - Production process designed with a focus on reducing } \\
\text { energy and resource consumption } \\
\text { V31 - Production planning and control focused on reducing } \\
\text { waste and optimising the consumption of materials } \\
\text { V32 - Acquisition of cleaner technologies and equipment } \\
\text { V33 - Preference for green products in purchases } \\
\text { V34 - Environmental criteria in supplier selection } \\
\text { V35 - Selection of less polluting transportation } \\
\text { V36 - Reusable or recyclable packaging in logistics activities }\end{array}$ & González-Benito and González-Benito (2006) \\
\hline GP indicators & $\begin{array}{l}\text { V37 - Reduction in greenhouse gas emissions } \\
\text { V38 - Reduction in water consumption }\end{array}$ & $\begin{array}{l}\text { Jeswani, Wehrmeyer, and Mulugetta (2008) } \\
\text { Jeswani and Azapagic (2011) }\end{array}$ \\
\hline
\end{tabular}


Table 1. (Continued)

\begin{tabular}{|c|c|c|}
\hline Construct & Variables/items/indicators & Adapted from \\
\hline & V39 - Reduction in solid waste & Bare and Gloria (2008) \\
\hline & V40 - Reduction in electric power consumption & Svensson et al. (2006) \\
\hline & V41 - Decrease in hazardous/toxic material consumption & Bare and Gloria (2008) \\
\hline & V42 - Decrease in environmental accident frequency & Hunt and Auster (1990) \\
\hline & $\begin{array}{l}\text { V43 - Improvement in the environmental situation of the } \\
\text { company }\end{array}$ & Wittneben and Kiyar (2009) \\
\hline \multirow[t]{6}{*}{ OP indicators } & $\begin{array}{l}\text { V44 - Reduction in operating costs (supply, production and } \\
\text { delivery) }\end{array}$ & Kumar and Kropp (2006) \\
\hline & $\begin{array}{l}\text { V45 - Reduction in the time needed to create and deliver new } \\
\text { products }\end{array}$ & $\begin{array}{l}\text { Bertolini et al. (2007) and Dominguez-Péry, } \\
\text { Ageron and Neubert (2013) }\end{array}$ \\
\hline & V46 - Successful new product launches & $\begin{array}{l}\text { Asif and Mandviwalla (2005), Cannon et al. } \\
\text { (2008), Dominguez-Péry, Ageron, and Neubert } \\
\text { (2013) and }\end{array}$ \\
\hline & V47 - Increase in product quality (compliance with requisites) & Tang and Yun (2008) \\
\hline & $\begin{array}{l}\text { V } 48 \text { - Increase in flexibility to conform to the different } \\
\text { requests from clients }\end{array}$ & $\begin{array}{l}\text { Lee and Schwarz (2007) and Cannon et al. } \\
(2008)\end{array}$ \\
\hline & $\begin{array}{l}\text { V } 49 \text { - Improvement in the capacity to comply with client } \\
\text { deadlines }\end{array}$ & $\begin{array}{l}\text { Asif and Mandviwalla (2005) and Dominguez- } \\
\text { Péry, Ageron, and Neubert (2013) }\end{array}$ \\
\hline
\end{tabular}

Based on Lebanese companies, Massoud et al. (2010) discovered the lack of government support and incentives, the lack of clear benefits and the lack of legal requests formed the main barriers to ISO 14001 certification. Walker, Di Sisto and McBain (2008), in an explorative study based on interviews from seven different private and public sector organisations, discovered that barriers to environmental supply chain management experienced by organisations tend to be both internal and external. Regarding IBs, cost concerns were a major barrier in two out of the seven investigated projects; secondly, the lack of legitimacy of environmental supply issues acts as a major obstacle. However, regarding EBs, several obstacles, such as lack of information, confidentiality concerns or fear of poor environmental performance exposure, all stem from factors such as poor suppliers' commitment or a low level of trust between customers and suppliers, each of which indicates suboptimal relationships.

Recently, Zhu and Geng (2013) studied the barriers to implementation of sustainable supply chains in China. IBs, such as the lack of monetary gains, resources and capability, are the main obstacles for implementation of sustainable customer cooperation. Thus, overcoming these IBs is key for Chinese manufacturers to effectively and efficiently implement sustainable supply chains, focusing on energy saving and emission reduction among Chinese manufacturers.

Abdulrahman, Gunasekaran and Subramanian (2014) found four key categories of barriers to the adoption of reverse logistics in China: a lack of reverse logistics experts and low commitment, a lack of initial capital and funds for return monitoring systems, a lack of enforceable laws and government-supportive economic policies and, finally, a lack of systems for return monitoring. Many different proposals exist for categorising barriers (Bey, Hauschild, and McAloone 2013), but the division between internal and EBs remains as a dominant approach.

There is a widely accepted idea in the literature that IBs are most significant, as they challenge environmental management (Post and Altma 1994; Hillary 2004; Murillo-Luna, Garcés-Ayerbe, and Rivera-Torres 2007; Dahlmann, Brammer, and Millington 2008). Accordingly, Mittal and Sangwan (2014) state that IBs are root barriers that cause policy and economic barriers, and those internal organisational barriers should be mitigated first for effective implementation of GOPs. Thus, a clear understanding of barriers will help organisations prioritise better and manage their resources in an efficient and effective way (Luthra et al. 2011).

Table 1 demonstrates both the main internal and EBs to environmental management, according to Murillo-Luna, Garcés-Ayerbe and Rivera-Torres (2011). Each of these barriers may have a negative influence on the adoption of operational environmental management practices, as explained below. But research results about the prevalence of IBs versus EBs are still mixed (Luthra et al. 2015). Moreover, the relationship between internal and external aspects for adopting green management has yet to reach a critical level of evidence (Menguc, Auh, and Ozanne 2010). Consequently, the following research hypotheses can be stated:

- $\mathrm{H}_{1}$ - EBs negatively affect adoption of GOPs (when barriers are higher, adoption of practices will be lower).

- $\mathrm{H}_{2}$ - IBs negatively affect adoption of GOPs (when barriers are higher, adoption of practices will be lower). 
GP refers to the assessment of actual results (measurements) of a system that seeks to reduce environmental problems by developing and improving policies and procedures that aim at a better relationship among objectives, goals and sustainability. Table 1 presents the concepts, variables and sources used in this research to define GP and to measure OP.

According to Cho and Gerchak (2005), OP may also be understood as efficiency in operations. If a company is efficient in its operations and is able to charge a low price and improve the availability of its products, the company is more competitive than other companies. In order to assess the OP presented by companies, we used a few performance indicators already utilised by Zhu, Sarkis and Lai (2007) in their OP assessment questionnaire directed to the Chinese automobile industry. We also surveyed other evidence found in the literature with respect to indicators and their interrelation with OP.

The GOPs can influence GP and OP indicators in companies, as some recent studies suggest. Some of these recent studies explore the relationship between themes of green operations and a firm's performance. Hajmohammad et al. (2012) indicate that supply management and lean activities provide a means by which resources are invested in environmental practices. Their empirical analysis also confirms that the impact of lean management on environmental performance, and to a lesser extent on supply management, is mediated by environmental practices. Finally, Wiengarten and Pagell (2012) indicated that it is certainly important to confirm that investments in environmental practices improve OP. However, it is also important to note that in this current and ever-increasing competitive business environment, it is of pivotal importance for companies to gain higher benefits through combining environmental with quality investments.

Thus, it is clearly necessary to integrate green issues in operations for firms to achieve better performance. However, literature has yet to reach a definitive consensus on this matter. For example, González-Benito and González-Benito (2005) noted that environmental management could improve performance, but that some environmental practices produced negative effects. Additionally, Aragon-Correa and Sharma (2003) noted that green management's effects on firm performance may face some influence from external and contextual issues, with unpredictable effects. Thus,

- $\mathrm{H}_{3}$ - GOPs positively affect OP.

- $\mathrm{H}_{4}$ - GOPs positively affect GP.

Considering that the relationship between operations and performance is still a major theme for contemporary research (Hassini, Surti, and Searcy 2012); if EB and IB can negatively influence GP and OP indicators, as affirmed by the literature, it could be acceptable that EB and IB can indirectly affect performance. For example, the lack of environmental training could be considered a barrier that may avoid the correct adoption of advanced GOP and consequently may negatively affect GP (Teixeira, Jabbour, and Jabbour 2012). As a consequence,

- $\mathrm{H}_{5}-$ EBs negatively mediate GP.

- $\mathrm{H}_{6}$ - IBs negatively mediate GP.

Abdulrahman, Gunasekaran and Subramanian (2014) also relate barriers to GOPs (reverse logistics) and performance. For these authors, the lack of a clear link between GOPs and performance can itself be a barrier. Knowing more about the relationship between green barriers and performance could help managers select organisational initiatives that will improve companies' performance, as Mittal and Sangwan (2014) determined, but this kind of analysis must consider the context in which the companies exist (Walker, Di Sisto, and McBain 2008). For example, in developing countries, where more research on sustainability is necessary (Gunasekaran, Jabbour, and Jabbour 2014), a contingency approach has been also adopted in Chinese studies (see, for example, Abdulrahman, Gunasekaran and Subramanian 2014). Thus,

- $\mathrm{H}_{7}$ - EBs negatively mediate OP.

- $\mathrm{H}_{8}$ - IBs negatively mediate OP.

Based on the literature review and both direct hypotheses $\left(\mathrm{H}_{1}, \mathrm{H}_{2}, \mathrm{H}_{3}\right.$ and $\left.\mathrm{H}_{4}\right)$ and indirect hypotheses $\left(\mathrm{H}_{5}, \mathrm{H}_{6}, \mathrm{H}_{7}\right.$ and $\mathrm{H}_{8}$ ), as stated throughout Section 2, Figure 1 outlines the conceptual framework to be empirically tested in this research.

\section{Methodology}

\subsection{Research and constructs' measurements definition}

This research offers a quantitative study, based on the survey strategy, that attempts to test the conceptual framework illustrated in Figure 1. The constructs/variables of the framework can be defined as: 


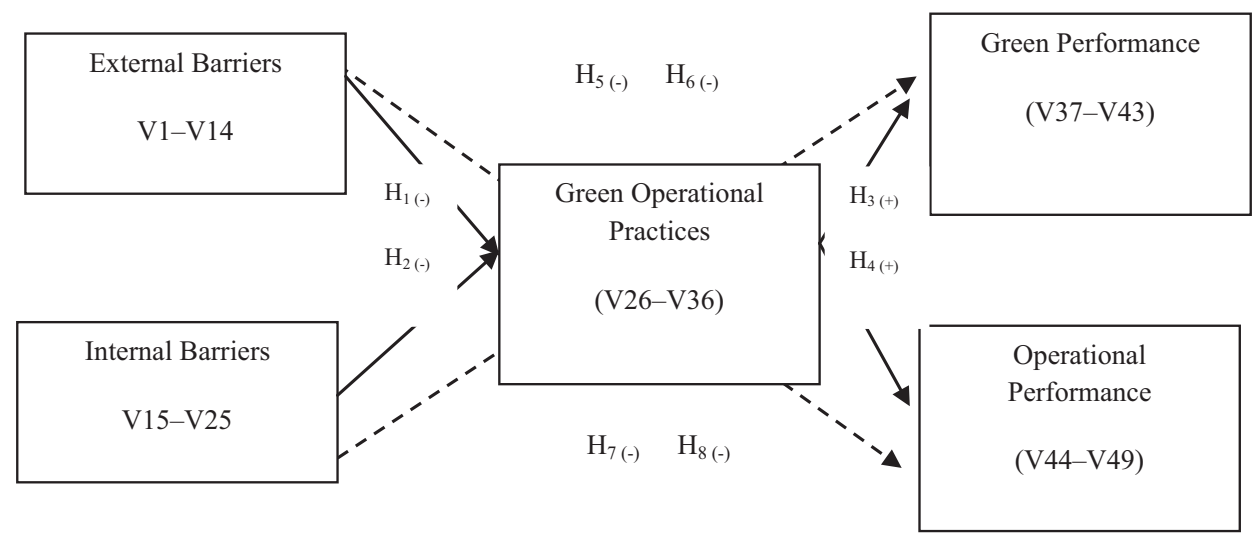

Figure 1. Conceptual model used in the research, with direct and mediated relationships. Direct effects; Mediated (Indirect) effects; $(-)$ negative effect; $(+)$ positive effect.

- Barriers to environmental management were measured considering two groups: external environmental barriers (EBs) and internal environmental barriers (IBs). The variables shown in Table 1 were used in a questionnaire. Each variable led to an assertive sentence, totalling 25 questions. Each item was measured using a five-point Likert scale ranging from 1 (strongly disagree) to 5 (strongly agree).

- Green operation practices (GOPs) follow the definitions contained in Table 1. Each item was measured using a five-point Likert scale ranging from 1 (not implemented) to 5 (fully implemented).

- OP indicators were measured according to the variables shown in Table 1. Each variable was converted into a statement inserted in the questionnaire. Each of these items was similarly measured using a five-point Likert scale ranging from 1 (much worse) to 5 (much better).

- GP indicators were measured according to Table 1. Again, each item was measured using a five-point Likert scale ranging from 1 (much worse) to 5 (much better).

- Finally, company size was considered as a control variable. According to Collins et al. (2007), large companies are more strongly involved in sustainable practices. The explanation for this finding entails the internal and external pressures for them to become involved in environmental activities. López-Gamero, Molina-Azorín and ClaverCortés (2009) share this same perspective and state that large companies tend to be leaders in their sectors. For Hourneaux et al. (2013), the use of GP is a greater concern for larger, rather than for smaller, firms. The size of the firm was measured using four categories: micro-, small-, medium-sized or large companies. We used the Brazilian classification for the size of firms, which is based on the number of company employees (Sebrae 2013). Micro-firms have up to 19 employees, small firms have between 20 and 99 employees, medium-sized firms have between 100 and 499 employees and large firms have 500 or more employees. According to Gonzalez-Benito and González-Benito (2006), firm size plays a major role when discussing corporate environmental management. Additionally, Josefy et al. (2015) considered firm size a key variable when studying organisational issues. Because of this, other possible variables were not considered as relevant as firm size.

\subsection{Population, sample and data collection}

According to Flynn et al. (1990), the operations management research field may earn benefits from a survey because the survey collects empirical real-world evidence and includes the perceptions of knowledgeable practitioners in the field of study. A questionnaire was created based on the information of Section 3.1.

From the Inmetro (Brazilian Institute for Quality and Metrology) database, with about 1000 industrial companies' profiles (after excluding service sector), it was possible to gather such information as firm names, names of potential respondents and respondent contact information, including email addresses and telephone numbers. Listed companies were from industrial and manufacturing sectors, including, primarily automotive, equipment, electronics and plastics industries. The questionnaires were sent through email to the potential respondents (business owners/managers) and telephone calls were made to increase the response rate. The research was performed during four months of 2012. The profile of the respondents included operations and production managers or equivalent authorities. There was only one respondent per firm. 
The gathered data resulted in a spreadsheet where a preliminary analysis of questionnaires was conducted. From a total of 82 questionnaires, 7 were eliminated (with missing values), so 75 were considered valid and used. This sample could be considered as small and a limitation of the present work, but we believe that the small number of respondents did not affect the research results negatively. On the other hand, the number of respondents in this research is near to the quantity of respondents to others' well-established works in the field of green production. See, for example, Holt and Ghobadian (2009) with 60 respondents, Rao (2002) with 52 respondents and Klassen and Whybark (1999) with about 70 respondents. Other studies exhibit smaller samples than this work's sample (Gavronski, Ferrer, and Paiva 2008). Some rules were applied to prove that this sample is small, but does not invalidate this study. Using Cohen's (1992) rule, the minimal sample size is 65 (power $80 \%$, significance level of $5 \%, \mathrm{R}^{2}<0.25$ and minimum number of arrows pointing at a construct $<4$ ). Additionally, using $\mathrm{G}^{*}$ Power, the minimum recommended sample size for this study is 68 , (power $=0.80$, effect size $=0.15$, significance level $5 \%$ and number of predictors 2 ). Ned Kock's rule shows that 69 respondents is the minimum acceptable to this research. Thus, with all the applied rules, this work has a sample size larger than the minimum acceptable size. Finally, when analysing the return rate, this sample is equal to a $7.5 \%$ return rate, which is similar to return rates of surveys in the field of operations management (Synodinos 2003) and similar to others' works on green management; see, for example, Pereira-Moliner et al. (2012), who had a return rate of $6.6 \%$ and Murillo-Luna, Garcés-Ayerbe and Rivera-Torres (2011) who had a return rate of about 6\%. Thus, considering some previous research, based on minimum sample rules and based on the return rate, we can consider our sample small, but still robust enough to warrant the proposed research model. Regarding the firms' size, $9.35 \%$ is micro-sized, $28.04 \%$ is small-sized, $39.25 \%$ is middle-sized and $23.36 \%$ are large-sized accordingly to the Brazilian pattern. Regarding the manufacturing activities performed by the sample's firms, according to the International Standard Industrial Classification of All Economic Activities (ISIC), the majority of them were classified as manufacturers of electrical equipment, basic metals, pharmaceutical products, machinery, transport equipment or chemicals. To ensure that the sample in this study may be representative, we checked this using a graph segmentation of WarpPLS software (Kock 2013). Results showed that no heterogeneity occurs in the data, so it can be concluded that these data-sets may fairly represent a population sample. We also compared the statistical data provided by the Brazilian Institute of Geography and Statistics (IBGE) for some attributes in the data-set (e.g. average firm size and average number of employees); we determined that the sample is quite similar to the Brazilian manufacturing sector.

Sample limitations will be discussed further in the conclusion section.

\subsection{Data analysis}

The hypotheses of the conceptual model were tested based on empirical data by means of structural equation modelling (Peng and Lai 2012) using partial least squares (PLS) with the support of the software WarpPLS 4.0. With WarpPLS software, researchers can test indirect effects automatically, as well as missing values/collinearity problems, and also some statistical indices. Thus, WarpPLS is a powerful variance-based SEM approach. The reason we choose PLS is because of its minimal demand measurement scales, distribution assumptions and that it can test complex conceptual frameworks. Structural equation modelling is a second-generation multivariate statistical analysis method that has gained attention in the areas of green management (Murillo-Luna, Garcés-Ayerbe, and Rivera-Torres 2011; Pereira-Moliner et al. 2012) and operations management (Peng and Lai 2012). The test of the conceptual model involves obtaining a measurement model (outer model) and a structural model (inner model).

We chose to adopt the perspective of reflective indicators, considered the dominant perspective in the field of operations management studies (Large and Thomsen 2011). Eight hypotheses were tested for this research, as explained in Section 3.1. We applied the cut-off values during the data analysis as follows. To evaluate the outer model, the following points should be noted:

- For assessing convergent validity, the outer loadings or items reliability must be higher than 0.7 , but values higher than 0.5 are acceptable and the average variance extracted (AVE) must be higher than 0.5.

- For assessing discriminant validity, the square roots' AVE must be higher than the correlations among the constructs.

- For assessing internal consistency reliability, we used composite reliability, which must be higher than 0.7 .

To evaluate the inner model, we considered the following cut values:

- First, we see the adjusted R-square for the stronger prediction/explain variance. Adjusted R-square $\leq 0.25$ is small, $\leq 0.45$ is medium and $\leq 0.70$ is large (Latan and Ghozali 2014).

- To evaluate fit indices, we tested APC, ARS, AARS, AVIF, AFVIF and GoF. 
- For APC, ARS and AARS, a result where $\mathrm{p}<0.05$ indicates good model fit (Kock 2013).

- Next, for AVIF and AFVIF, if the result $<5$, this indicates that the model does not have problems concerning vertical and lateral collinearities (Kock and Lynn 2012).

- $\mathrm{GoF} \geq 0.10$ is small, $\geq 0.25$ is medium and $\geq 0.36$ is large (Latan and Ghozali 2012).

- We ran resampling methods for results with significance p-value with a Stable method and PLS regression algorithm. The Stable method will result in the same p-value if we ran the model more than once. The PLS regression algorithm is designed to minimise the collinearity problem.

Using a t-test, the possibility of a non-response bias was examined by comparing the first and last waves of respondents on all the examined variables (Dillman, Smyth, and Christian 2014). We also used the Wilcoxon test for comparison. There were no statistically significant differences $(p<0.01)$, which implies no systematic non-response bias that would affect the results. Finally, each proposed research hypothesis will be tested and judged as either 'rejected' or 'accepted'.

\section{Research results}

Each of these constructs was of sufficient quality for statistical methods and indicators, and includes the AVE, reliability and composite reliability measures. EBs had some variables excluded: V1, V7, V9, V10, V11, V12, V13 and V14. The model has been run without these variables again. The relatively high number of excluded variables may be explained by cultural differences between Brazilian management and management in countries for which the original scales were designed.

When analysing the three biggest loads of variables for each construct (Table 2), the EBs with the highest weight are V4, V3 and V5, respectively. That is, 'Lack of flexibility in compliance with legal deadlines', 'Difficulties associated with the environmental legislation application and monitoring process' and 'Lack of flexibility in compliance with legal demands'.

For IBs, the three variables with the highest loads were V23, V25 and V22, in that order, representing 'directors/ owners have limited environmental awareness', 'directors/owners resist changes in work habits' and 'employees have limited environmental awareness'.

For GOPs, the variables with the biggest weights were V30, V33 and V27, respectively, indicating the importance of 'Production process designed with a focus on reducing energy and resource consumption', 'Preference for green products in purchases' and 'Product development focused on reducing consumption of materials and waste generation during production and distribution'.

The main variables for GP were V38, V39 and V41, which are 'We reduced water consumption', 'We reduced solid waste' and 'We reduced the consumption of hazardous/toxic materials', respectively.

Finally, OP variables with the highest weights were V47, V49 and V45, which are 'We increased product quality (meeting requirements)', 'We improved our capacity to meet client deadlines' and 'We reduced the time needed to create and deliver new products'.

Convergent validity (Table 2) as well as discriminant validity (Table 3) revealed satisfactory values. Convergent validity verified that most variables indeed had greater load in the construct of origin.

The results of discriminant validity show that the square roots of average variances extracted (AVEs), shown on diagonal, are higher than the other values. Results also show that all the loads are higher in the construct of origin. Thus, these results show a high enough level of statistical adequacy.

Regarding the empirical test of the proposed framework, we considered all the statistical indicators with a sufficient level of quality (Table 4). In terms of direct relations, EBs were not as significant as IBs during implementation of GOPs.

These GOPs, in turn, affect performance indicators (GP and OP) to a 'small' degree effect. GP is more determined by GOPs than by OP, based on the values of Adjusted $\mathrm{R}^{2}$. In terms of indirect relations, EBs tend not to relate significantly to performance (GP and $\mathrm{OP}$ ).

Figure 2 summarises the path diagram model and Table 5 shows the relationships between the variables.

Table 5 presents a systematisation of the level of significance for direct and mediated relations, considering a $p$ value $<0.05$ as the baseline for determining significance.

Based on these findings, from the eight proposed hypotheses, five have been accepted and three rejected, as seen in Table 6.

Company size does not interfere significantly in OP and GP. The general result of the statistical adjustment of the (GoF) model also proved adequate and large in the context of a PLS approach because GoF $=0.508$. Additionally, other 
Table 2. Convergent validity and internal consistency reliability results.

\begin{tabular}{|c|c|c|c|c|}
\hline Constructs & Variables/items/indicators & Indicator reliability & AVE & Composite reliability \\
\hline \multirow[t]{6}{*}{ External barriers } & $\mathrm{V} 2$ & 0.715 & & \\
\hline & $\underline{\mathrm{V} 3}$ & 0.796 & & \\
\hline & $\underline{\mathrm{V} 4}$ & 0.840 & & \\
\hline & $\underline{\mathrm{V} 5}$ & 0.784 & 0.533 & 0.871 \\
\hline & $\overline{\mathrm{V} 6}$ & 0.624 & & \\
\hline & V8 & 0.585 & & \\
\hline \multirow[t]{10}{*}{ Internal barriers } & V16 & 0.603 & & \\
\hline & V17 & 0.658 & & \\
\hline & V18 & 0.688 & & \\
\hline & V19 & 0.657 & & \\
\hline & V20 & 0.679 & & \\
\hline & V21 & 0.719 & 0.509 & 0.911 \\
\hline & $\underline{\mathrm{V} 22}$ & 0.795 & & \\
\hline & $\underline{\overline{\mathrm{V} 23}}$ & 0.832 & & \\
\hline & $\overline{\mathrm{V} 24}$ & 0.641 & & \\
\hline & $\underline{\mathrm{V} 25}$ & 0.824 & & \\
\hline \multirow[t]{11}{*}{ Green operational practices } & $\overline{\mathrm{V} 26}$ & 0.738 & & \\
\hline & $\underline{\mathrm{V} 27}$ & 0.811 & & \\
\hline & $\mathrm{V} 28$ & 0.779 & & \\
\hline & V29 & 0.522 & & \\
\hline & $\underline{\mathrm{V} 30}$ & 0.832 & & \\
\hline & $\bar{V} 31$ & 0.793 & 0.579 & 0.937 \\
\hline & V32 & 0.761 & & \\
\hline & $\underline{\mathrm{V} 33}$ & 0.812 & & \\
\hline & $\overline{\mathrm{V} 34}$ & 0.738 & & \\
\hline & V35 & 0.791 & & \\
\hline & V36 & 0.75 & & \\
\hline \multirow[t]{7}{*}{ Green performance } & V37 & 0.781 & & \\
\hline & $\underline{\mathrm{V} 38}$ & 0.873 & & \\
\hline & $\underline{\mathrm{V} 39}$ & 0.837 & & \\
\hline & $\overline{\mathrm{V} 40}$ & 0.813 & 0.635 & 0.924 \\
\hline & $\underline{\mathrm{V} 41}$ & 0.831 & & \\
\hline & $\overline{\mathrm{V} 42}$ & 0.686 & & \\
\hline & V43 & 0.742 & & \\
\hline \multirow[t]{6}{*}{ Operational performance } & V44 & 0.758 & & \\
\hline & $\underline{\mathrm{V} 45}$ & 0.780 & & \\
\hline & $\overline{\mathrm{V} 46}$ & 0.733 & & \\
\hline & $\underline{\mathrm{V} 47}$ & 0.848 & 0.597 & 0.898 \\
\hline & $\overline{\mathrm{V} 48}$ & 0.655 & & \\
\hline & $\underline{\mathrm{V} 49}$ & 0.845 & & \\
\hline
\end{tabular}

Note: Items with low outer loadings were already removed and the model was run again.

Table 3. Discriminant validity results.

\begin{tabular}{lccccrr}
\hline & EB & IB & GOP & GP & OP & Size \\
\hline EB & $(0.730)$ & 0.329 & -0.091 & -0.105 & -0.138 & -0.124 \\
IB & 0.329 & $(0.714)$ & -0.502 & -0.429 & -0.451 & -0.094 \\
GOP & -0.091 & -0.502 & $(0.761)$ & 0.816 & 0.517 & 0.100 \\
GP & -0.105 & -0.429 & 0.816 & $0.797)$ & 0.532 & -0.167 \\
OP & -0.138 & -0.451 & 0.517 & 0.167 & $-0.033)$ & $(1.000)$ \\
Size & -0.124 & -0.094 & 0.100 & & \\
\hline
\end{tabular}

Note: Square roots of AVEs are shown on diagonal.

measures for testing the model's fit were significant, such as $\mathrm{SRMR}=0.882 ; \mathrm{APC}=0.353, \mathrm{p}<0.001 ; \mathrm{ARS}=0.402$, $\mathrm{p}<0.001 ;$ AARS $=0.385, \mathrm{p}<0.001$. Finally, the AVIF and AFVIF (AVIF $=1.047$; AFVIF $=1.995$ ) indicated the model did not have problems concerning vertical/lateral collinearity and also common method bias. 
Table 4, Inner model analysis results.

\begin{tabular}{lccccc}
\hline Latent variables & R-squared $\left(\mathrm{R}^{2}\right)$ & Adjusted $\left(\mathrm{R}^{2}\right)$ & Effect size $\left(\mathrm{f}^{2}\right)$ & $\mathrm{Q}^{2}$ Predictive validity & Full collinearity VIF \\
\hline External barriers & - & - & 0.008 & - & 1.146 \\
Internal barriers & - & - & 0.265 & - & 1.595 \\
Green operational practices $\rightarrow$ GP & 0.258 & 0.237 & 0.658 & 0.260 & 3.330 \\
Green operational practices $\rightarrow$ OP & & & 0.271 & 0.671 & 3.251 \\
Green performance & 0.673 & 0.664 & - & 0.270 & 1.576 \\
Operational performance & 0.274 & 0.254 & - & \\
\hline
\end{tabular}

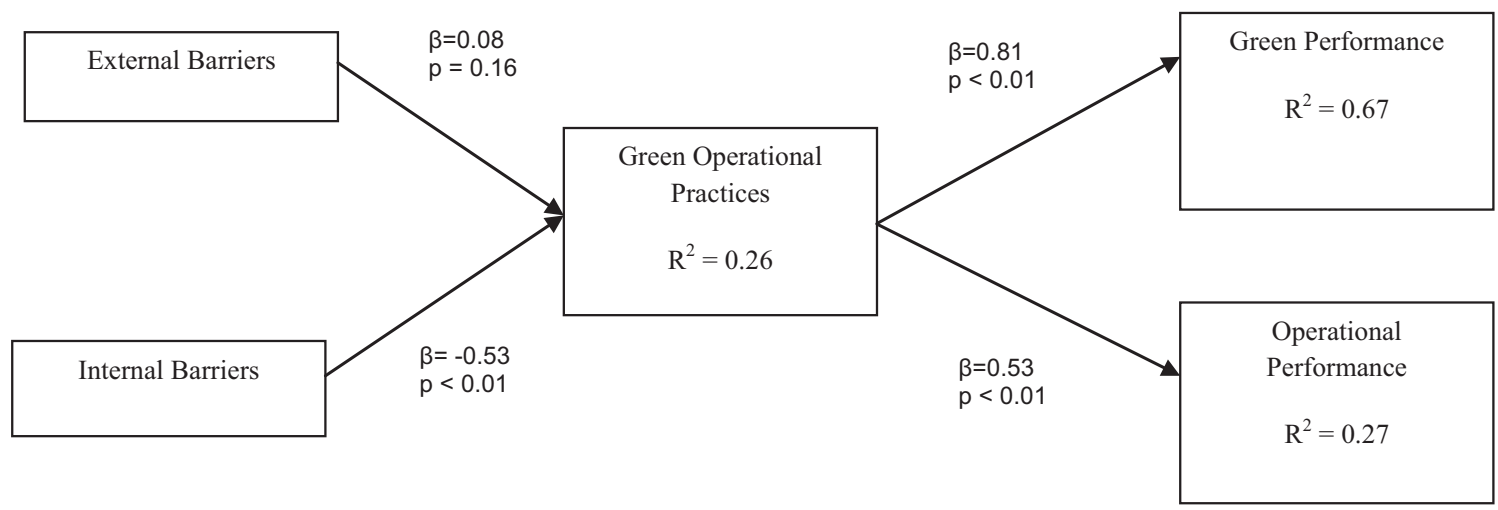

Figure 2. Result path diagram model - test of the main hypotheses.

Table 5. Relationships among variables (testing hypotheses $\rightarrow$ Sig. 5\%).

\begin{tabular}{|c|c|c|c|c|}
\hline Relationship & $\begin{array}{l}\text { Standard } \\
\text { error }\end{array}$ & $\begin{array}{c}\mathrm{P}- \\
\text { value }\end{array}$ & $\begin{array}{l}\text { Sig. direct } \\
\text { effect }\end{array}$ & $\begin{array}{l}\text { Sig. indirect } \\
\text { effect }\end{array}$ \\
\hline External barriers $\rightarrow$ green operational practices & 0.116 & 0.237 & No & - \\
\hline Internal barriers $\rightarrow$ green operational practices & 0.098 & 0.000 & Yes & - \\
\hline Green operational practices $\rightarrow$ green performance & 0.045 & 0.000 & Yes & - \\
\hline Green operational practices $\rightarrow$ operational performance & 0.093 & 0.000 & Yes & - \\
\hline External barriers $\rightarrow$ green operational Practices $\rightarrow$ green performance & 0.094 & 0.238 & - & No \\
\hline $\begin{array}{l}\text { External barriers } \rightarrow \text { green operational practices } \rightarrow \text { operational } \\
\text { performance }\end{array}$ & 0.061 & 0.238 & - & No \\
\hline Internal barriers $\rightarrow$ green operational practices $\rightarrow$ green performance & 0.085 & 0.000 & - & Yes \\
\hline $\begin{array}{l}\text { Internal barriers } \rightarrow \text { green operational practices } \rightarrow \text { operational } \\
\text { performance }\end{array}$ & 0.082 & 0.000 & - & Yes \\
\hline
\end{tabular}

\section{Discussion}

The first set of theoretical implications shows that IBs are more relevant than EBs when adopting GOPs. This result confirms that if companies want to build competitive advantages as suggested by natural resource-based view of the firms (Hart 1995), they need to deal with IBs and to focus on increasing the level of green awareness of managers and offering sufficient green training. Human skills appear as relevant resources to overcome the main IBs, through green training and awareness (which are in line with the results of Teixeira, Jabbour and Jabbour 2012). Based on the ecological modernisation theory, we can suggest that the simple initiation/publication of NPSW is not enough to promote a greener industrial context in Brazil. Government will need to provide the offering, transferring and generating of green knowledge between firms of all sizes.

Thus, a conjugation between ecological modernisation issues (firms' external context) and natural resources-based view (firms' internal context) will be necessary to connect new green laws, to overcome IB and to improve performance. 
Table 6. Results: test of hypotheses.

\begin{tabular}{lll}
\hline Hypotheses & Result & Reason \\
\hline $\begin{array}{l}\mathrm{H}_{1}-\text { EBs negatively affect adoption of GOPs (when barriers are higher, adoption of } \\
\text { practices will be lower) }\end{array}$ & Rejected & p-value $>0.05$ \\
$\mathrm{H}_{2}-$ IBs negatively affect adoption of GOPs (when barriers are higher, adoption of & Accepted beta -0.53 ; p-value $<0.001$ \\
practices will be lower) & & \\
$\mathrm{H}_{3}-$ GOPs positively affect OP & Accepted beta 0.53 ; -value $<0.001$ \\
$\mathrm{H}_{4}-$ GOPs positively affect GP & Accepted beta $0.81 ; \mathrm{p}$-value $<0.001$ \\
$\mathrm{H}_{5}-$ EBs negatively mediate GP & Rejected beta 0.068 ; -value 0.238 \\
$\mathrm{H}_{6}-$ IBs negatively mediate GP & Accepted beta -0.427 - \\
& value $<0.001$ \\
$\mathrm{H}_{7}-$ EBs negatively mediate OP & Rejected beta $0.044 ;$-value 0.238 \\
$\mathrm{H}_{8}-$ IBs negatively mediate OP & Accepted beta $-0.278 ; \mathrm{p}-$ \\
& & value $<0.001$ \\
\hline
\end{tabular}

In this context, investment should be directed mainly to explore the relationships between green issues, quality and flexibility in operations management. Secondly, the good statistical adjustment of the research framework shows that in green management themes, more synergistic and systematic frameworks, although more complex to analyse, can be useful for understanding sustainability issues (Gunasekaran and Ngai 2012). This more systemic result, with a more complex and empirically tested framework, adds empirical evidence to conceptual studies on green barriers (Hillary 2004) and can add a broader perspective to studies that analysed the relation between environmental barriers and practices (Jabbour and Puppim-de-Oliveira 2012) or the relation between green management and company performance (González-Benito and González-Benito 2005). According to Mittal and Sangwan (2014)'s suggestion, this paper also extends the literature by adding evidence from the Brazilian context.

In terms of the result of this framework test, it was verified that company size tends not to have a significant influence on green and OP. This result is contrary to what is indicated in some similar studies and it requires further attention in future studies (González-Benito and González-Benito 2006; Horneaux et al. 2013). This result can indicate that firms, despite their different sizes, can face barriers to environmental management in a similar manner, mainly because their barriers exist in the same context, i.e. Brazil. This finding adds to the discourse among existing works that affirm large companies have better conditions to deploy environmental management when compared to smaller companies (Hillary 2004; González-Benito and González-Benito 2006; Jabbour and Puppim-de-Oliveira 2012). Considering the natural resource-based view of the firms (Hart 1995; Sarkis, Zhu, and Lai 2011; Dangelico 2015), this result indicates that higher GP and OP are not dependent on a firm's size, and therefore, the creation of green value can be done also for smaller companies.

When observing the research hypotheses, of the eight declared hypotheses, five were considered valid. In terms of direct relations, IBs are inversely proportional to the adoption of GOPs, confirming existing findings of the literature (Murillo-Luna, Garcés-Ayerbe, and Rivera-Torres 2011); in other words, the more intense the internal barrier, the lower the tendency for adopting GOPs. GOPs also tend to influence a company's green and OP directly, with a stronger influence on GP; therefore, green practices tend to improve organisational competitiveness (López-Gamero, Molina-Azorín, and Claver-Cortes 2011; Gotschol, De Giovanni, and Esposito Vinzi 2014). EBs, in turn, had no significant relation to the adoption of GOPs. Although it may seem surprising, this result had been indicated in the literature, and it affirms that the IBs are more harmful to the adoption of green management practices at companies (Hillary 2004; Murillo-Luna, Garcés-Ayerbe, and Rivera-Torres 2011). This result may also be explained by the fact that all of the studied companies are based on a physical location in Brazil, and are subject to a similar set of green laws. They also all need to adapt to the NPSW. Ecological modernisation efforts will require practical actions from the Brazilian Government because IBs tend to be more representative than EBs. Results also may indicate that green value, according to the natural resourcesbased view theory, will come mainly from the link between GOPs and GP, confirming the results of Wong, Wong and Boon-itt (2013) and Wong et al. (2012). Ultimately, the success of GOPs will depend on providing sufficient green awareness and training to managers.

The use of Warp 4.0 - partial least squares - automatically provides measures of mediated effects between constructs. Thus, the analysis of mediated relations is another contribution of this study. As per the analysis of hypotheses, it was observed that IBs to GOPs indirectly affect companies' GPs and OPs. Thus, managers who tend to improve operational and GP indicators of the companies at which they work should not only adopt GOPs, but should also consider IBs to green management. EBs to green management did not prove to be indirectly related to OP and EP. 
These results show the importance of IBs to green management when adopting operational green practices (González-Benito and González-Benito 2006) and their implications for company operational and GP. Once again, as per previous indications in the literature, the greater, significant importance of IBs compared to EBs to green management is confirmed (Hillary 2004). Thus, organisational managers, when seeking the adoption of GOPs and, consequently, improving company GP and OP, should attack the IBs first and systematically because IBs should be mitigated initially for the most effective implementation of GOPs (Mittal and Sangwan 2014). As consequence, a clear understanding of barriers will help organisations prioritise better and manage their resources in an efficient and effective way (Luthra et al. 2011). The relevance of IBs can also be explained by some characteristics of Brazilian management which requires attention to particular internal issues of the companies (Caldas and Wood 1997).

Finally, analysing each of the constructs, the main concern for EBs should fall on the environmental legislation, as, for example, NPSW, but this kind of ecological modernisation initiative will only work if IBs are considered firstly. For IBs, attention should be given to top management and its awareness on green issues, confirming the relevance of green training and awareness as articulated throughout the literature (Jabbour 2013; Teixeira, Jabbour, and Jabbour 2012). For GOPs, emphasis should be given to the production process and to the preference for environmentally appropriate suppliers, although this preference does not necessarily lead to the incorporation of environmental aspects in the supplier selection process, confirming the results of Wong et al. (2012). The result has been highlighted by the literature on green supplier selection (Genovese et al. 2013), on quality issues (Gravonski et al. 2011) and on flexibility (Wong, Wong, and Boon-itt 2013) which are also relevant, and could be considered even more relevant if companies want to create truly green value (Hart 1995; Wong, Wong, and Boon-itt 2013). In terms of performance, it is necessary to focus on themes such as reducing water consumption and cutting the generation of waste and toxic/hazardous materials because the ecological modernisation in Brazil is acting through a strong waste elimination due to NPSW's purpose (Jabbour et al. 2014). Only a few studies considered reducing water consumption as a GP indicator, but in this research, this variable was considered relevant, as suggested by Jeswani and Azapagic (2011). In operational terms, themes such as quality, delivery deadlines and time to market proved relevant, showed that GOPs could have a synergic relationship with GOPs to promote greater sustainability (Schrettle et al. 2014).

\section{Conclusions}

Based on ecological modernisation and natural resource-based view theories, the objective of this study was twofold: to verify to what degree the direct and indirect relations exist between internal and external green barriers (IBs and EBs) and to investigate the adoption of GOPs and firms' performance (GP and OP) using data from Brazilian companies, especially considering firms that are dealing with a new set of green laws such as NPSW.

Research results and implications lead to the following main conclusions:

- IBs are much more significant that EBs during the adoption of GOPs, and those practices tend to influence a company's GP and OP. IBs also indirectly influence a company's GP and OP indicators more than EBs. IBs' relevance in this context can be explained by the characteristics of Brazilian management (Caldas and Wood 1997) and deserves future research.

- These results extend the literature showing that ecological modernisation through new environmental laws should be combined with initiatives to overcome IBs, mainly providing training and promoting green awareness to firms' managers. Industrial associations and universities can help in this process, establishing partnerships (Wang et al. 2013) for green training (Muduli et al. 2013). Firms looking for green value can observe performance improvement through the adoption of GOPs, mainly by selecting green suppliers and a greening production process. Regardless of the company's size, a deep understanding of IBs will be necessary to move industrial greening in Brazil forward in a timely manner.

Some limitations to this study exist in terms of sample size. The sample of this study can be considered small, but still sufficient in terms of statistics. A larger sample is really desirable for any future research. Results are based only on the Brazilian context, but they may provide insights to other emerging economies and individuals interested in doing business in Brazil. We strongly suggest that a similar research framework be tested in a cross-country study and also explore the subject of barriers to green services operations (Wong, Wong, and Boon-itt 2013). Specifically, the differences or synergies between internal and EBs should be further investigated. Also, this research did not adopt 'industrial sector' as a control variable, which could be improved in future research. Other control variables, such as debt ratio, level of internationalisation and age, can also be adopted in further research models. We might also highlight the potential bias effect because the research results are based on managers' perceptions, only using a single respondent approach, which can be complemented by more sophisticated data collection procedures. Social desirability bias has become a 
concern in sustainability studies, as the respondents try to perform as they believe interviewers expect. Under this circumstance, less accurate responses can be obtained (Roxas and Lindsay 2012). Additionally, this study's research sample did not represent the distribution of ISO 9001 sectors and firms across Brazil. Finally, the insignificant loading for many EB items deserves future research in order to verify how managerial idiosyncrasies and other aspects may be related to the low level of adherence to the items of the construct EB.

\section{Disclosure statement}

No potential conflict of interest was reported by the authors.

\section{Funding}

This research was partially supported by CNPq - The Brazilian National Research and Development Council [grant \#400101/2013-0]; Kannan Govindan's research is partially supported by Forsknings-og Innovationsstyrelsen for Project [4070-00139B].

\section{References}

Abdulrahman, M. D., A. Gunasekaran, and N. Subramanian. 2014. "Critical Barriers in Implementing Reverse Logistics in the Chinese Manufacturing Sectors.” International Journal of Production Economics 147: 460-471.

Angell, L. C., and R. D. Klassen. 1999. "Integrating Environmental Issues into the Mainstream: An Agenda for Research in Operations Management." Journal of Operations Management 17 (5): 575-598.

Aragon-Correa, J. A., and S. Sharma. 2003. "A Contingent Resource-based View of Proactive Corporate Environmental Strategy." Academy of Management Review 28 (1): 71-88.

Asif, Z., and M. Mandviwalla. 2005. "Integration of Supply Chain with RFID." Communications of the Association for Information Systems 15: 393-427.

Bare, J. C., and T. P. Gloria. 2008. "Environmental Impact Assessment Taxonomy Providing Comprehensive Coverage of Midpoints, Endpoints, Damages, and Areas of Protection." Journal of Cleaner Production 16 (10): 1021-1035.

Bertolini, M., E. Bottani, A. Rizzi, and M. Bevilacqua. 2007. "Lead Time Reduction through ICT Application in the Footwear Industry: A Case Study." International Journal of Production Economics 110 (1-2): 198-212.

Bey, N., M. Z. Hauschild, and T. C. McAloone. 2013. "Drivers and Barriers for Implementation of Environmental Strategies in Manufacturing Companies." CIRP Annals - Manufacturing Technology 62: 43-46.

Burgos-Jiménez, J., D. Vázquez-Brust, J. A. Plaza-Úbeda, and J. Dijkshoorn. 2013. "Environmental Protection and Financial Performance: An Empirical Analysis in Wales." International Journal of Operations and Production Management 33: $981-1018$.

Caldas, M. P., and T. Wood. 1997. "For the English to See: The Importation of Managerial Technology in Late 20th-Century Brazil." Organization 4 (4): 517-534.

Cannon, A. R., P. M. Reyes, G. V. Frazier, and E. L. Prater. 2008. "RFID in the Contemporary Supply Chain: Multiple Perspectives on the Benefits and Risks." International Journal of Operations and Production Management 28 (5): $433-454$.

Chan, E. S. 2008. "Barriers to EMS in the Hotel Industry." International Journal of Hospitality Management 27: $187-196$.

Chan, E. S. W. 2011. "Implementing Environmental Management Systems in Small and Medium Sized Hotels: Obstacles." Journal of Hospitality \& Tourism Research 35 (3): 3-23.

Cho, R. K., and Y. Gerchak. 2005. "Supply Chain Coordination with Downstream Operating Costs: Coordination and Investment to Improve Downstream Operating Efficiency.” European Journal of Operational Research 162 (3): 762-772.

Cohen, J. 1992. "A Power Primer." Psychological Bulletin 112 (1): 155-159.

Collins, E., S. Lawrence, K. Pavlovich, and C. Ryan. 2007. "Business Networks and the Uptake of Sustainability Practices: The Case of New Zealand." Journal of Cleaner Production 15: 729-740.

Cordano, M., R. S. Marshall, and M. Silverman. 2010. “How Do Small and Medium Enterprises Go 'Green'? A Study of Environmental Management Programs in the US Wine Industry." Journal of Business Ethics 92: 463-478.

Dahlmann, F., S. Brammer, and A. Millington. 2008. "Barriers to Proactive Environmental Management in the U.K.: Implications for Business and Public Policy.” Journal of General Management 33 (3): 1-20.

Dangelico, R. M. in press. "Improving Firm Environmental Performance and Reputation: The Role of Employee Green Teams." Business Strategy and the Environment 24 (8): 735-749.

Dillman, D. A., J. D. Smyth, and L. M. Christian. 2014. Internet, Phone, Mail, and Mixed Mode Surveys: The Tailored Design Method. 4th ed. Hoboken, NJ: Wiley.

Dominguez-Péry, C., B. Ageron, and G. Neubert. 2013. "A Service Science Framework to Enhance Value Creation in Service Innovation Projects: An RFID Case Study." International Journal of Production Economics 141 (2): 440-451.

Ervin, D., J. Wu, M. Khanna, C. Jones, and T. Wirkkala. 2013. "Motivations and Barriers to Corporate Environmental Management." Business Strategy and the Environment 22: 390-409. 
Flynn, B. B., S. Sakakibara, R. G. Schroeder, K. A. Bates, and E. J. Flynn. 1990. "Empirical Research Methods in Operations Management." Journal of Operations Management 9 (2): 250-284.

Gavronski, I., G. Ferrer, and E. L. Paiva. 2008. "ISO 14001 Certification in Brazil: Motivations and Benefits." Journal of Cleaner Production 16 (1): 87-94.

Gavronski, I., R. D. Klassen, S. Vachon, and L. F. M. Nascimento. 2011. “A Resource-based View of Green Supply Management.” Transportation Research Part E: Logistics and Transportation Review 47 (6): 872-885.

Genovese, A., L. S. C. Koh, G. Bruno, and E. Esposito. 2013. "Green Supplier Selection: State of Art and Some Empirical Evidence." International Journal of Production Research 51 (10): 2868-2886.

González-Benito, J., and Ó. González-Benito. 2005. "Environmental Proactivity and Business Performance: An Empirical Analysis." Omega 33 (1): 1-15.

González-Benito, J., and Ó. González-Benito. 2006. "A Review of Determinant Factors of Environmental Proactivity.” Business Strategy and the Environment 15 (2): 87-102.

Gotschol, A., P. De Giovanni, and V. Esposito Vinzi. 2014. "Is Environmental Management an Economically Sustainable Business?" Journal of Environmental Management 144: 73-82.

Grant, R. M. 2002. The Resource-based Theory of Competitive Advantage. Strategy: Critical Perspectives on Business and Management 33 (3): 114-135.

Gunasekaran, A., and E. W. Ngai. 2012. "The Future of Operations Management: An Outlook and Analysis." International Journal of Production Economics 135 (2): 687-701.

Gunasekaran, A., C. J. C. Jabbour, and A. B. L. S. Jabbour. 2014. "Managing Organizations for Sustainable Development in Emerging Countries: An Introduction.” International Journal of Sustainable Development and World Ecology 21 (3): $195-197$.

Gupta, M. C. 1995. "Environmental Management and its Impact on the Operations Function." International Journal of Operations \& Production Management 15 (8): 34-51.

Hajmohammad, S., S. Vachon, R. D. Klassen, and I. Gavronski. 2012. "Lean Management and Supply Management: Their Role in Green Practices and Performance." Journal of Cleaner Production 39: 312-320.

Handfield, R. B., S. V. Walton, L. K. Seegers, and S. A. Melnyk. 1997. “'Green' Value Chain Practices in the Furniture Industry.” Journal of Operations Management 15 (4): 293-315.

Handfield, R. B., S. Melnyk, R. J. Calantone, and S. Curkovic. 2001. "Integrating Environmental Concerns into the Design Process: The Gap Between Theory and Practice." Engineering Management, IEEE Transactions 48 (2): 189-208.

Hart, S. L. 1995. “A Natural-resource-based View of the Firm.” Academy of Management Review 20 (4): 986-1014.

Hart, Stuart L., and Glen Dowell. 2011. "A Natural-resource-based View of the Firm: Fifteen Years After." Journal of Management 37 (5): 1464-1479.

Hassini, E., C. Surti, and C. Searcy. 2012. "A Literature Review and a Case Study of Sustainable Supply Chains with a Focus on Metrics." International Journal of Production Economics 140 (1): 69-82.

Hillary, R. 2004. "Environmental Management Systems and the Smaller Enterprise." Journal of Cleaner Production 12: 561-569.

Holt, D., and A. Ghobadian. 2009. "An Empirical Study of Green Supply Chain Management Practices Amongst UK Manufacturers." Journal of Manufacturing Technology Management 20 (7): 933-956.

Hourneaux Jr. F., H. A. Hrdlicka, C. M. Gomes, and I. Kruglianskas. 2013. "The Use of Environmental Performance Indicators and Size Effect: A Study of Industrial Companies.” Ecological Indicators 36: 205-212.

Hunt, C. B., and E. R. Auster. 1990. "Proactive Environmental Management: Avoiding the Toxic Trap." MIT Sloan Management Review 31 (2): 7-18.

Jabbour, C. J. C., and A. B. L. S. Jabbour. 2014. "Latin America: Research Opportunities on Management for Sustainable Development." Latin American Journal of Management for Sustainable Development 1 (1): 1-4.

Jabbour, C. J. C., and J. A. Puppim-de-Oliveira. 2012. "Barriers to Environmental Management in Clusters of Small Businesses in Brazil and Japan: From a Lack of Knowledge to a Decline in Traditional Knowledge." International Journal of Sustainable Development \& World Ecology 19 (3): 247-257.

Jabbour, A. B. L., C. J. C. Jabbour, J. Sarkis, and K. Govindan. 2014. "Brazil's New National Policy on Solid Waste: Challenges and Opportunities." Clean Technologies and Environmental Policy 16 (1): 7-9.

Jeswani, H. K., and A. Azapagic. 2011. "Water Footprint: Methodologies and a Case Study for Assessing the Impacts of Water Use." Journal of Cleaner Production 19 (12): 1288-1299.

Jeswani, H. K., W. Wehrmeyer, and Y. Mulugetta. 2008. "How Warm is the Corporate Response to Climate Change? Evidence from Pakistan and the UK." Business Strategy and the Environment 17 (1): 46-60.

Josefy, M., S. Kuban, R. Ireland, and M. Hitt. 2015. "All Things Great and Small: Organizational Size, Boundaries of the Firm, and a Changing Environment." The Academy of Management Annals 9 (1): 715-802.

Kehbila, A. G., J. Ertel, and A. C. Brent. 2009. "Strategic Corporate Environmental Management within the South African Automotive Industry: Motivations, Benefits, Hurdles." Corporate Social Responsibility Environmental and Management 16: 310-323.

Klassen, R. D., and D. C. Whybark. 1999. "The Impact of Environmental Technologies on Manufacturing Performance." Academy of Management Journal 42 (6): 599-615.

Kock, N., 2013. WarpPLS 4.0 User Manual. Laredo, TX: ScriptWarp Systems. 
Kock, N., and G. S. Lynn. 2012. "Lateral Collinearity and Misleading Results in Variance-Based SEM: An Illustration and Recommendations." Journal of the Association for Information Systems 13 (7): 546-580.

Kuei, C. H., W. S. Chow, C. N. Madu, and J. P. Wu. 2013. "Identifying Critical Enablers to High Performance Environmental Management: An Empirical Study of Chinese Firms." Journal of Environmental Planning and Management 56 (8): $1152-1179$.

Kumar, S., and J. Kropp. 2006. "Studying the Operational Efficiencies of a Multi-product Supply Chain using Excel Spreadsheet Model." Technovation 26 (10): 1186-1200.

Lai, K. H., C. W. Wong, and T. C. E. Cheng. 2012. "Ecological Modernisation of Chinese Export Manufacturing via Green Logistics Management and its Regional Implications." Technological Forecasting and Social Change 79 (4): 766-770.

Large, R. O., and C. Gimenez Thomsen. 2011. "Drivers of Green Supply Management Performance: Evidence from Germany." Journal of Purchasing and Supply Management 17: 176-184.

Latan, H., and I. Ghozali. 2012. Partial Least Squares: Concepts, Techniques and Application using program SmartPLS 2.0 M3. 1st ed. Semarang: Diponegoro University Press.

Latan, H., and I. Ghozali. 2014. Partial Least Squares: Concepts, Methods and Application using Program WarpPLS 4.0. 2nd ed. Semarang: Diponegoro University Press.

Lee, J. Y., and L. Schwarz. 2007. "Lead Time Reduction in a (Q, r) Inventory System: An Agency Perspective." International Journal of Production Economics 105 (1): 204-212.

Leonidou, L. C., P. Christodoulides, L. P. Kyrgidou, and D. Palihawadana. in press. Internal Drivers and Performance Consequences of Small Firm Green Business Strategy: The Moderating Role of External Forces. Journal of Business Ethics, 1-22.

Lin, C., and Y. Ho. 2011. "Determinants of Green Practice Adoption for Logistics Companies in China." Journal of Business Ethics 98 (1): 67-83.

López-Gamero, M. D., J. F. Molina-Azorín, and E. Claver-Cortés. 2009. "The Whole Relationship between Environmental Variables and Firm Performance: Competitive Advantage and Firm Resources as Mediator Variables." Journal of Environmental Management 90: 3110-3121.

López-Gamero, M. D., J. F. Molina-Azorín, and E. Claver-Cortes. 2011. "The Relationship between Managers' Environmental Perceptions, Environmental Management and Firm Performance in Spanish Hotels: A Whole Framework." International Journal of Tourism Research 13: 141-163.

Luthra, S., V. Kumar, S. Kumar, and A. Haleem. 2011. "Barriers to Implement Green Supply Chain Management in Automobile Industry using Interpretive Structural Modeling Technique: An Indian Perspective.” Journal of Industrial Engineering and Management 4 (2): 231-257.

Luthra, S., S. Kumar, D. Garg, and A. Haleem. 2015. "Barriers to Renewable/Sustainable Energy Technologies Adoption: Indian Perspective." Renewable and Sustainable Energy Reviews 41: 762-776.

Martín-de Castro, G., J. Amores-Salvadó, and J. E. Navas-López. in press. Environmental Management Systems and Firm Performance: Improving Firm Environmental Policy through Stakeholder Engagement. Corporate Social Responsibility and Environmental Management.

Massoud, M. A., R. Fayad, M. El-Fadel, and R. Kamleh. 2010. "Drivers, Barriers and Incentives to Implementing Environmental Management Systems in the Food Industry: A Case of Lebanon.” Journal of Cleaner Production 18 (3): 200-209.

Massoud, M. A., N. Makarem, W. Ramadan, and R. Nakkash. 2015. "Environmental Management Practices in the Lebanese Pharmaceutical Industries: Implementation Strategies and Challenges.” Environmental Monitoring and Assessment 187 (3): 1-10.

Menguc, B., S. Auh, and L. Ozanne. 2010. "The Interactive Effect of Internal and External Factors on a Proactive Environmental Strategy and its Influence on a Firm's Performance.” Journal of Business Ethics 94 (2): 279-298.

Mittal, V. K., and K. S. Sangwan. 2014. "Development of a Model of Barriers to Environmentally Conscious Manufacturing Implementation." International Journal of Production Research 52 (2): 584-594.

Muduli, K., K. Govindan, A. Barve, D. Kannan, and Y. Geng. 2013. "Role of Behavioural Factors in Green Supply Chain Management Implementation in Indian Mining Industries." Resources, Conservation and Recycling 76: 50-60.

Murillo-Luna, J. L., C. Garcés-Ayerbe, and P. Rivera-Torres. 2007. "What Prevents Firms from Advancing in their Environmental Strategy?" International Advances in Economic Research 13 (1): 35-46.

Murillo-Luna, J. L., C. Garcés-Aybere, and P. Rivera-Torres. 2011. "Barriers to Adoption of Proactive Environmental Strategies." Journal of Cleaner Production 19 (13): 1417-1425.

Peng, D. X., and F. Lai. 2012. "Using Partial Least Squares in Operations Management Research: A Practical Guideline and Summary of Past Research." Journal of Operations Management 30 (6): 467-480.

Pereira-Moliner, J., E. Claver-Cortés, J. F. Molina-Azorín, and J. J. Tarí. 2012. "Quality Management, Environmental Management and Firm Performance: Direct and Mediating Effects in the Hotel Industry." Journal of Cleaner Production 37: 82-92.

Post, J. E., and B. W. Altman. 1994. "Managing the Environmental Change Process: Barriers and Opportunities." Journal of Organizational Change Management 7 (4): 64-81.

PriceWaterhouseCoopers. 2015. "The World in 2050 - Will the Shift in Global Economic Power Continue?" Accessed August 2015. www.pwc.co.uk/economics

Rao, P. 2002. "Greening the Supply Chain: A New Initiative in South East Asia." International Journal of Operations \& Production Management 22 (6): 632-655. 
Roxas, B., and V. Lindsay. 2012. "Social Desirability Bias in Survey Research on Sustainable Development in Small Firms: An Exploratory Analysis of Survey Mode Effect.” Business Strategy and the Environment 21 (4): 223-235. doi:10.1002/bse.730.

Sala-I-Martín, X., B. Bilbao-Osorio, A. Di Battista, M. Drzeniek, H. C. Galvan, and T. Geiger. 2014. The Global Competitiveness Index 2014-2015: Accelerating a Robust Recovery to Create Productive Jobs and Support Inclusive Growth - The Global Competitiveness Report 2014-2015, 978-992. Geneva: In World Economic Forum Publication. ISBN-13.

Sarkis, J., Q. Zhu, and K. H. Lai. 2011. “An Organizational Theoretic Review of Green Supply Chain Management Literature.” International Journal of Production Economics 130 (1): 1-15.

Schaltegger, S., and T. Synnestvedt. 2002. "The Link between 'Green' and Economic Success: Environmental Management as the Crucial Trigger between Environmental and Economic Performance.” Journal of Environmental Management 65: $339-346$.

Schrettle, S., A. Hinz, M. Scherrer-Rathje, and T. Friedli. 2014. "Turning Sustainability into Action: Explaining Firms' Sustainability Efforts and their Impact on Firm Performance.” International Journal of Production Economics 147: 73-84.

Schroeder, R. G., Kimberly A. Bates, and M. A. Junttila. 2002. "A Resource-based View of Manufacturing Strategy and the Relationship to Manufacturing Performance." Strategic Management Journal 23 (2): 105-117.

Sebrae. 2013. "Critérios de classificação de empresas: EI - ME - EPP.” Accessed July 30. http://www.sebraesc.com.br/leis/default. asp?vedtexto $=4154$

Sharma, S., and H. Vredenburg. 1998. "Proactive Corporate Environmental Strategy and the Development of Competitively Valuable Organizational Capabilities.” Strategic Management Journal 19 (8): 729-753.

Shi, H., S. Z. Peng, Y. Lui, and P. Zhong. 2008. "Barriers to the Implementation of Cleaner Production in Chinese SMEs: Government, Industry and Expert Stakeholders' Perspectives.” Journal of Cleaner Production 16: 842-852.

Studer, S., R. Welford, and P. Hills. 2006. "Engaging Hong Kong Business in Environmental Change: Drivers and Barriers." Business Strategy and the Environment 15: 416-431.

Svensson, N., L. Roth, M. Eklund, and A. Mårtensson. 2006. "Environmental Relevance and Use of Energy Indicators in Environmental Management and Research." Journal of Cleaner Production 14 (2): 134-145.

Synodinos, N. E. 2003. "The 'Art' of Questionnaire Construction: Some Important Considerations for Manufacturing Studies." Integrated Manufacturing Systems 14 (3): 221-237.

Tang, X., and H. Yun. 2008. "Data Model for Quality in Product Lifecycle." Computers in Industry 59 (2-3): 167-179.

Teixeira, A. A., C. J. C. Jabbour, and A. B. L. D. S. Jabbour. 2012. "Relationship between Green Management and Environmental Training in Companies Located in Brazil: A Theoretical Framework and Case Studies." International Journal of Production Economics 140 (1): 318-329.

Terziovski, M., D. Power, and A. S. Sohal. 2003. "The Longitudinal Effects of the ISO 9000 Certification Process on Business Performance." European Journal of Operational Research 146 (3): 580-595.

Ubeda, S., F. J. Arcelus, and J. Faulin. 2011. "Green Logistics at Eroski: A Case Study." International Journal of Production Economics 131 (1): 44-51.

Wagner, M. 2005. "How to Reconcile Environmental and Economic Performance to Improve Corporate Sustainability: Corporate Environmental Strategies in the European Paper Industry.” Journal of Environmental Management 76: 105-118.

Walker, H., L. Di Sisto, and D. McBain. 2008. "Drivers and Barriers to Environmental Supply Chain Management Practices: Lessons from the Public and Private Sectors." Journal of Purchasing and Supply Management 14: 69-85.

Wang, Y., H. Shi, M. Sun, D. Huisingh, L. Hansson, and R. Wang. 2013. "Moving Towards an Ecologically Sound Society? Starting from Green Universities and Environmental Higher Education.” Journal of Cleaner Production 61: 1-5.

White House, US. 2015. "US-Brazil Joint Statement on Climate Change." Accessed October 2015. https://www.whitehouse.gov/thepress-office/2015/06/30/us-brazil-joint-statement-climate-change

Wiengarten, F., and M. Pagell. 2012. "The Importance of Quality Management for the Success of Environmental Management Initiatives." International Journal of Production Economics 140: 407-415.

Wittneben, B. B., and D. Kiyar. 2009. "Climate Change Basics for Managers.” Management Decision 47 (7): $1122-1132$.

Wong, C. W., K. H. Lai, K. C. Shang, C. S. Lu, and T. K. P. Leung. 2012. "Green Operations and the Moderating Role of Environmental Management Capability of Suppliers on Manufacturing Firm Performance." International Journal of Production Economics 140 (1): 283-294.

Wong, C. W., C. Y. Wong, and S. Boon-itt. 2013. "Green Service Practices: Performance Implications and the Role of Environmental Management Systems.” Service Science 5 (1): 69-84.

Zhu, Q., and Y. Geng. 2013. "Drivers and Barriers of Extended Supply Chain Practices for Energy Saving and Emission Reduction among Chinese Manufacturers." Journal of Cleaner Production 40: 6-12.

Zhu, Q., J. Sarkis, and K. Lai. 2007. "Green Supply Chain Management: Pressures, Practices and Performance within the Chinese Automobile Industry.” Journal of Cleaner Production 15: 1041-1052. 